\title{
Abram alas para os heróis de barracões: uma análise sobre a importância histórica do carnaval carioca para a cultura do país ${ }^{1}$
}

Júlia Rivero de Souza Massoto

Pontifícia Universidade Católica do Rio de Janeiro - PUC-Rio

Departamento de Comunicação Social - Bacharelado em Jornalismo

\section{Resumo}

Este artigo ressalta a importância histórica do carnaval e do samba e resgata personagens de extrema relevância para a cultura do Brasil, silenciados ou apagados por parte da voz hegemônica. O trabalho tem como pano de fundo o enredo da Mangueira de 2019 e se apoia prioritariamente nas pesquisas de SIMAS e LOPES. São destacados o protagonismo negro, indígena e feminino nas lutas travadas contra o sistema escravocrata e a resistência pela liberdade. O estudo evidencia a importância dos heróis e heroínas de barracões, que fazem, de fato, o carnaval acontecer. As semelhanças entre os heróis da História e dos barracões são um dos pontos centrais deste trabalho.

Palavras-chave: Mangueira; Carnaval; Samba; Escola de Samba; Barra.

\section{Introdução}

Quando uma escola de samba desfila na Avenida, muita coisa atravessa junto com ela, não apenas seus integrantes, os carros alegóricos e o pessoal da bateria. Quando uma agremiação cruza a Marquês de Sapucaí, uma história é contada e cantada pelos foliões. Durante aqueles 65 minutos, os olhos do mundo estão voltados para a alegria coletiva que o samba provoca e para o enredo que está sendo apresentado durante aquele curto período, a ancestralidade da escola é sentida naquele momento, e o refrão salta pela boca do povo. Cada desfile carrega consigo uma história que foi estudada e desenvolvida durante o ano inteiro, há aqueles sambas-enredo que sempre serão lembrados e entoados por muitas gerações. Quem não sabe cantar os versos empolgantes do Salgueiro de 1993 com seu "explode coração"2? Ou o Bum

\footnotetext{
${ }^{1}$ Artigo derivado de monografia de graduação em Jornalismo, orientada pela professora Lilian Saback e entregue em junho de 2020.

2 Samba-enredo do Salgueiro de 1993: Peguei um Ita no Norte. Autores do samba: Demá Chagas, Arizão, Bala, Guaracy e Celso Trindade. O enredo foi inspirado na canção "Peguei um Ita no Norte" de Dorival Caymmi, que narra a viagem costeira a bordo do vapor Itapé quando o compositor baiano migrou em 1938 para o Rio de Janeiro.
} 
Bum Paticumbum Prugurundum do Império Serrano de $1982^{3}$ ? Sambas de décadas diferentes, mas que continuam sendo cantados em fins de festa por todos, do mais novo ao mais velho.

As escolas, quando desfilam, levam um fragmento da nossa história. Resgatam do passado heróis que não costumamos estudar nas escolas, personagens anônimos ou pouco reconhecidos de sua importância. O carnaval tem um papel fundamental de reforçar as raízes do nosso país a cada fevereiro ${ }^{4}$ e nos educar com seus enredos pelo resto do ano. A importância histórica que o carnaval tem para a cultura do país é enorme. "As escolas de samba - junto a seu par, o samba-enredo, e o produto final, o desfile - souberam ao longo de sua história reconfigurar seu discurso, dialogando, polifonicamente, com setores cada vez mais abrangentes e diversos." (GOMES, 2014, p.14).

O carnaval é a resistência de uma cultura que não se deixa dominar e ao longo dos anos vem se modificando para estar sempre de acordo com o tempo e o espaço em que vivemos. $O$ resgate da história brasileira que os enredos das escolas de samba vêm apresentando nos últimos anos denota a luta e a resistência que há no samba em sempre se reafirmar como parte indissociável da cultura do país. Por isso, "na condição de cultura popular, o samba se transforma num potencial espaço de fala daquilo que passamos a chamar de categorias subalternas." (GOMES, 2014, p. 15).

Para pensar a importância histórica dos enredos foi estudado o samba-enredo da Mangueira de 2019, que reforça a importância de abordar a luta indígena e negra, a resistência das mulheres, e evidenciar a supervalorização de personagens engrandecidos por terem "vencido" apenas porque estiveram do lado mais forte da história. Porém, os heróis esquecidos atravessaram a Avenida da Verde e Rosa e marcaram presença na Sapucaí justamente em um cenário político em que o apagamento de pautas importantes e de personalidades com extrema relevância para a história do nosso país é uma tendência atualmente.

O samba-enredo da Mangueira dialoga perfeitamente com a concepção de que o samba e o carnaval servem como espaço de fala para as classes subalternas, uma vez que os próprios integrantes da Escola, em sua maioria, estavam representando heróis e heroínas que fazem

\footnotetext{
${ }^{3}$ Samba-enredo do Império Serrano de 1982: Bum Bum Paticumbum Prugurundum. Autores do samba: Beto sem Braço e Aluízio Machado. O enredo surgiu a partir de uma entrevista de Ismael Silva sobre as origens do samba carioca. Nasce então, um questionamento sobre as diferenças entre os segmentos do samba. Assim, cria-se a onomatopeia do refrão do samba-enredo.

${ }^{4}$ Devido ao agravamento da pandemia o carnaval de 2021 foi adiado para 2022.
} 
parte da história brasileira, mas que não estão nos livros de História, como Esperança Garcia $(1751-?)^{5}$, Chico da Matilde $(1839-1914)^{6}$ e tantos outros.

O objetivo deste trabalho é ressaltar a importância dos enredos das Escolas de Samba no resgate da história brasileira e analisar as razões pelas quais o desfile da Mangueira em 2019 cumpriu de maneira precisa esse papel social e político. A Verde e Rosa levou para Avenida o tema "História para ninar gente grande" 7 em que destacava os personagens esquecidos ou silenciados da cultura brasileira. O desfile abordou pautas como o protagonismo negro e indígena, a luta e a força feminina e as contranarrativas, que consiste em mostrar a pouca valorização e visibilidade de personalidades oprimidas e engrandecer os atores que tinham a função do opressor.

O samba-enredo cantado e apresentado na Marquês de Sapucaí traz figuras da história que são importantes de serem homenageadas e estudadas, e reforça o destaque que a academia vem dando cada vez mais para essas pautas e personagens. Por isso, levar para a avenida tal enredo faz com que a Mangueira cumpra um papel educacional para a população.

O artigo está dividido em duas partes: na primeira, é ressaltada a importância do enredo e do samba-enredo para se contar uma história, sobretudo, a do nosso país. Na segunda, se analisa o enredo e o samba-enredo da Mangueira de 2019 e apresenta os personagens que foram citados no samba e no desfile, figuras históricas pouco conhecidas da nossa cultura.

\section{O Carnaval e a História Brasileira de Mãos Dadas}

A história da cultura brasileira é formada por diversos elementos, o samba, sem dúvida, é um dos atores centrais dessa composição. Ele nasce na década de 1920, no morro do Estácio, bairro que sofreu o processo de exclusão social devido às reformas urbanas promovidas pelo então prefeito Pereira Passos (1902-1906). O dirigente tinha como objetivo modernizar a cidade do Rio de Janeiro e transformá-la em vitrine para turistas, assim, "pôs abaixo os

\footnotetext{
${ }^{5}$ Esperança Garcia (1751-?) foi uma mulher negra escravizada brasileira, considerada a primeira mulher advogada do Piauí. Em 6 de setembro de 1770, Esperança enviou uma petição ao então presidente da Província de São José do Piauí, Gonçalo Lourenço Botelho de Castro, em que denuncia maus-tratos e abusos físicos contra ela e seu filho pelo feitor da Fazenda Algodões.

${ }^{6}$ Francisco José do Nascimento (1839-1914), também conhecido como Chico da Maltide ou Dragão do Mar, foi um líder jangadeiro, prático mor e abolicionista, com participação ativa no movimento Abolicionista no Ceará, que foi o estado pioneiro na abolição da escravidão.

7 "História para ninar gente grande" foi o enredo escolhido e desenvolvido pelo carnavalesco Leandro Vieira, em que apresenta um desfile sobre o carnaval dos marginalizados pela História do Brasil, defendendo os negros, pobres e indígenas. Autores do samba-enredo: Danilo Firmino, Deivid Domênico, Mama e outros.
} 
cortiços expulsando as populações mais pobres que passaram a ocupar os morros periféricos ao centro." (GOMES, 2014, p.28).

A região da Pequena África ${ }^{8}$, localizada na Zona Portuária do Rio, também é considerada berço do samba. Lá era o ponto de encontro de artistas, em sua maioria negros, que eram proibidos de se apresentar em público. Por isso, eles buscavam refúgio nas casas das tias baianas, e foi em uma dessas reuniões que nasceu o primeiro samba registrado no Brasil, "Pelo Telefone", composto por Donga ${ }^{9}$ e Mauro de Almeida ${ }^{10}$. Durante o regime escravagista, o local era um mercado de negros escravizados. Hoje, é um lugar onde se celebra a cultura afro-brasileira, como por exemplo, as rodas de samba que ocorrem toda segunda-feira, na Pedra do Sal. Deste modo, pode-se afirmar que a trajetória do samba e a história brasileira andam lado a lado, uma dando passagem para a outra.

Existem diferentes maneiras de se contar a história de um país, no caso brasileiro há muitos fatores que fazem com que a história do samba e do carnaval esteja diretamente ligada com a história brasileira. Os quase quatro séculos de escravidão praticados no país deixaram algumas heranças que foram incorporadas à cultura do Brasil. Destaca-se o samba, o carnaval, o pagode, a gastronomia, manifestações culturais como a capoeira, o jongo ${ }^{11}$, o coco ${ }^{12}$, 0 maracatu ${ }^{13}$, religiões de matriz africana e até mesmo características comportamentais dos brasileiros. Também deve ser analisado o racismo estrutural presente na nossa sociedade, outra herança e consequência da escravidão no país. Esse sistema muito contribui para o apagamento da identidade e cultura negra.

O que falta muitas vezes aos brasileiros é o entendimento do racismo como uma estrutura, a investigação sobre a origem social das desigualdades e de romper com essa visão, que ficou, infelizmente, muito popular no Brasil, porque foi feita por uma elite intelectual dessa

\footnotetext{
8 Área que compreende as "antigas localidades e freguesias da Cidade Nova, de Santana, do Santo Cristo, da Saúde e da Gamboa" (LOPES; SIMAS, 2015, p. 220). O local, onde comunidades baianas se estabeleceram a partir dos anos 1870, é considerado um importante polo de congruência entre as várias expressões da cultura de matriz africana, assim como o samba.

${ }^{9}$ Ernesto Joaquim Maria dos Santos, conhecido como Donga (1890-1974), foi um músico, compositor e violonista brasileiro. Participava das rodas de música na casa da famosa Tia Ciata, ao lado de João da Baiana, Pixinguinha e outros bambas. Em 1917, registrou "Pelo Telefone", que foi considerado o primeiro samba gravado da história brasileira.

10 Mauro de Almeida (1882-1956) foi um teatrólog, jornalista e compositor brasileiro. Mauro entrou para a história da música popular brasileira por ter escrito em coautoria com Donga a letra de "Pelo Telefone".

${ }^{11} \mathrm{O}$ jongo é uma dança de umbigada praticada ao som de tambores, trazido para o Brasil por negros Bantus, região compreendida hoje pelo território de Angola. A principal característica do jongo é a junção entre música e dança em que os integrantes da roda se desafiam por meio de improvisação de ladainhas e dançam em par. 12 O coco é uma dança de roda da região do Nordeste, a manifestação cultural surgiu nos engenhos de açúcar da antiga capitania de Pernambuco, com influências dos batuques africanos e dos bailados indígenas.

${ }^{13} \mathrm{O}$ maracatu é um ritmo musical, dança e ritual de sincretismo religioso com o estado de Pernambuco. Existem dois tipos: o Maracatu Nação (baque virado) e Maracatu Rural (baque solto). O primeiro é o mais antigo ritmo afrobrasileiro e o segundo é característico da cidade de Nazaré da Mata (Zona da Mata de Pernambuco).
} 
democracia racial, essa ideia romântica do "não conflitos raciais", isso dificultou muito o aprofundamento sobre a questão racial no Brasil. (RIBEIRO, 2020) ${ }^{14}$

A partir da década de 1930, que marca o início da Era Vargas (1930-1945), a ideia de mestiçagem começa a ganhar mais destaque, e o mito da democracia racial ${ }^{15}$ é difundido. Luiz Antonio Simas e Fábio Fabato destacam que o governo varguista:

(...) buscou legitimar as manifestações da cultura afro-brasileira como componentes fundamentais da identidade nacional. Ao fazer isso, buscava, certamente, manter essas manifestações sob o controle do poder público, domesticando-as e tirando delas, na medida do possível, os elementos africanos mais explícitos. O samba se insere nesse processo, assim como a capoeira e as práticas religiosas do candomblé e da umbanda. Para os governos, nada melhor, nessa perspectiva, do que agremiações oriundas das camadas pobres, compostas majoritariamente por negros, colocadas a serviço da difusão pedagógica de uma história oficial repleta de grandes efemérides e atos de heroísmo, amenizadoras de tensões raciais e sociais entre os brasileiros. O negro conta a história do branco. (SIMAS; FABATO, 2015, p. 26).

Devido ao contexto político-social da época, como conta Antonio Henrique de Castilho Gomes (2014), o papel do carnaval se transforma de acordo com as mudanças que ocorreram no governo Vargas, sobretudo, no período do Estado Novo ${ }^{16}$ em que buscava-se refundar as tradições e reinventar a ideia de nação brasileira. Assim,

(..) a dependência que o samba-enredo tem com seu par, o desfile, leva ao surgimento de sambas-enredo que colaboram com a invenção desta nova tradição da qual o samba também vai se beneficiar. A nova ideia de nação parte fundamentalmente da rejeição do caráter negativo atribuído ao aspecto mestiço da sociedade brasileira. O que antes era visto como fracasso, agora é a nossa mais importante tradição. É exatamente aí que o samba abre espaço para se transformar em símbolo nacional. (GOMES, 2014, p 52, 53).

É inegável que o carnaval e a história brasileira se confundem. Ao contar a trajetória do samba, esbarramos nos conflitos e contextos político-sociais do país ao longo dos séculos, nos

\footnotetext{
14 Trecho da entrevista da filósofa e escritora Djamila Ribeiro para o programa Roda Viva, concedida no dia 09/11/2020. Djamila é autora dos livros: O que é lugar de fala? Quem tem medo do feminismo negro? E o mais recente, Pequeno manual antirracista.

${ }^{15} \mathrm{O}$ mito da democracia racial foi difundido por meio do livro Casa-grande e Senzala, do sociólogo Gilberto Freyre em 1933, embora o termo nunca tenha sido cunhado pelo autor, a ideia de que o Brasil viva em harmonia com as três raças (negros, indígenas e brancos) foi amplamente divulgada após a publicação da obra e permanece no imaginário coletivo da população até os dias de hoje.

${ }^{16}$ Estado Novo é a denominação do período da história do Brasil compreendido entre 1937 e 1945 . Caracterizou-se por um governo ditatorial amparado por uma Constituição forte e um projeto nacionalista, voltado para o desenvolvimento industrial e a autonomia do país diante dos grupos econômicos internacionais. (LOPES; SIMAS, 2015, p. 124)
} 
avanços alcançados e nas mudanças constantes que o samba enfrenta. Analisar e estudar a história brasileira por meio dessa ótica é se permitir ficar bom da cabeça e melhor ainda do pé.

\subsection{0 enredo e o samba-enredo, juntos para contar uma história}

Em 1931, sambistas do bairro de Oswaldo Cruz, da escola Vai Como Pode, que mais tarde daria origem à Portela, reivindicaram pela primeira vez que a escola pudesse desenvolver um tema para apresentar no carnaval. Nessa década, segundo Luiz Antonio Simas e Nei Lopes (2015), os enredos tinham temas mais aleatórios e aspectos da natureza eram bem recorrentes na época. "Após a oficialização dos desfiles, com o poder público auxiliando as escolas de samba, a temática passou a ser dirigida para a exaltação, em tons de ufanismo, das grandes efemérides do Brasil e dos heróis e heroínas da história." (LOPES; SIMAS.2015, p. 109).

A mudança de abordagem definitiva deu início em 1959, com o Salgueiro trazendo o enredo sobre a obra do desenhista francês Jean Baptiste Debret, com efeitos visuais e temas sobre a cultura afro-brasileira que também começaram a aparecer. A escola Vermelha e Branca foi pioneira em apresentar enredos que traziam a negritude como destaque. Nos anos seguintes, vieram os enredos "Palmares", "Chica da Silva", "Aleijadinho" e "Chico Rei". Rompendo, portanto, com temas menos compromissados com a nossa história como era realizado no passado. Assim, os enredos começaram a ganhar mais peso e importância para os desfiles. (LOPES; SIMAS, 2014).

Nas últimas décadas, os temas dos enredos têm assumido um viés mais político-social muito em razão das mudanças que vêm acontecendo na sociedade brasileira. Pautas como o feminismo, o racismo, a homofobia e o machismo estão sendo debatidas e discutidas constantemente. Problemas que são estruturais, ou seja, estão enraizados na nossa cultura e que reproduzimos muitas vezes de maneira inconsciente, mas que precisam ser desconstruídos. O carnaval, por sua vez, leva para a Avenida essas questões e faz com que o público reflita sobre elas. Esse exercício é extremamente necessário para avançarmos enquanto sociedade, eis o papel social e educativo do samba.

Outro elemento crucial para o desfile é o samba-enredo. Ele é determinante para que uma escola tenha um bom desempenho no carnaval. O samba-enredo, necessariamente, precisa ter em seus versos referências ao enredo. Ambos caminham juntos para contar a história proposta pelo carnavalesco. Segundo Nei Lopes e Luiz Antonio Simas (2015), a partir da década de 1930, com a disputa entre as escolas, por meio de concursos, as agremiações passaram a exaltar personagens da história brasileira e a se comprometerem com os temas 
apresentados. Assim, veio a consagração do subgênero, na época, cunhado de samba de enredo.

\subsection{Os heróis e heroínas da História e dos barracões}

"Glória a quem trabalha o ano inteiro em mutirão/ São escultores, são pintores, bordadeiras/ São carpinteiros, vidraceiros, costureiras/ Figurinistas, desenhista e artesão/ Gente empenhada em construir a ilusão."

Os versos da canção de Martinho da Vila, "Pra Tudo se Acabar na Quarta-feira", exalta os heróis dos bastidores, aqueles que se esforçam incansavelmente ao longo do ano todo para fazer o carnaval acontecer. Esses trabalhadores são os mesmos que desfilam na Avenida representando muitos dos heróis e heroínas da nossa história. No entanto, o reconhecimento que se dá a esses personagens, tanto dos barracões quanto da história brasileira, não é proporcional à grandeza de ambos.

Em um verso do samba-enredo da Mangueira de 2019, a escola fazia um pedido: "Eu quero um país que não está no retrato". Esta frase simboliza a importância do resgate de personagens que fazem parte da história do Brasil e que foram silenciados. A Verde e Rosa, no entanto, com o enredo "História para ninar gente grande", reverencia os heróis e heroínas esquecidos e joga o holofote sobre eles.

Os atores da história brasileira que não estão nas páginas dos livros, em sua maioria, são formados por negros ou são de camadas mais baixas da sociedade. Essa realidade apenas ratifica o mito da democracia racial muito difundida no passado e que ainda reverbera nos dias de hoje. Essa premissa equivocada, e que deveria ser datada, faz com que o apelo da Mangueira seja muito necessário e urgente. Afinal, já passou da hora de sabermos quem são os heróis do nosso país, aqueles que lutaram e resistiram pela liberdade e pelos seus direitos.

Os heróis e heroínas dos barracões e da história têm muitos pontos em comum. Além da invisibilidade, a origem também é outro fator que os une. Ambos, majoritariamente, são negros e de classes sociais mais baixas, e por essa razão, tiveram suas trajetórias diminuídas ou apagadas pela história. Porém, na Mangueira do Brasil de muitos brasis, eles próprios foram protagonistas de suas histórias e nos contaram suas lutas, dores e superações. Na Avenida, os heróis dos barracões e da história se uniram formando um corpo só para cantar o mesmo canto e nos lembrar algo que muitas vezes é esquecido: a ancestralidade não se apaga. 


\section{A história que a História não conta}

A partir dos trechos de sambas-enredos da Mangueira da década de 1960, é possível observar que a escravidão e a questão racial eram abordadas pelo olhar do branco, do opressor e não pelos negros que lutaram pela liberdade e também fazem parte da história brasileira. Isso indica, mais uma vez, que a verdadeira história do Brasil é sempre podada e maquiada com o objetivo de não modificar, de maneira eficiente e definitiva, a estrutura social do país.

Pretos escravos e senhores/ Pelo mesmo ideal irmanados/ A desbravar os vastos rincões / Não conquistados [...]

(Mangueira, Casa-Grande e Senzala, 1962)

[...] Chegando à velha Bahia/ Preto velho foi vendido/ Menino a um senhor/Que amenizou a sua grande dor.

(Mangueira, História de um Preto Velho, 1964) ${ }^{17}$

Dando um salto para o século XXI, mais especificamente para o ano de 2019, a Mangueira decide, novamente, ter a negritude e outros grupos identitários que são excluídos socialmente como tema de seu enredo. No entanto, dessa vez, quem conta a história são os próprios negros. Os heróis e heroínas brasileiros ocuparam a Marquês de Sapucaí para nos apresentar suas trajetórias. Após esse carnaval, ficou evidente que não mais é preciso que ninguém conte a história por eles. Eles são a história, fazem parte dela, possuem voz e devem ser ouvidos. Abaixo o samba-enredo educativo e histórico da Mangueira 2019:

Mangueira, tira a poeira dos porões/ Ô, abre alas pros teus heróis de barracões/ Dos Brasis que se faz um país de Lecis, Jamelões/ São verde e rosa as multidões/ Brasil, meu nego/ Deixa eu te contar/ A história que a História não conta/ O avesso do mesmo lugar/ Na luta é que a gente se encontra/ Brasil, meu dengo/ A mangueira chegou/ Com versos que o livro apagou/ Desde 1500 tem mais invasão do que descobrimento/ Tem sangue retinto pisado/ Atrás do herói emoldurado/ Mulheres, tamoios, mulatos/ Eu quero um país que não está no retrato/ Brasil, o teu nome é Dandara/ E a tua cara é de Cariri/ Não veio do céu/ Nem das mãos de Isabel/ A liberdade é um dragão no mar de Acarati/ Salve os caboclos de julho/ Quem foi de aço nos anos de chumbo/ Brasil, chegou a vez/ De ouvir as Marias, Mahins, Marielles, Malês. ${ }^{18}$

O enredo apresentado pela Mangueira "História para ninar gente grande", desenvolvido pelo carnavalesco Leandro Vieira ${ }^{19}$, foi dividido em cinco setores. O primeiro, intitulado "Mais invasão do que descobrimento", trazia para a Avenida o protagonismo indígena. Os povos

\footnotetext{
17 Já em 1964, a Mangueira trouxe como enredo a história de um preto velho, em que o paternalismo do branco que protege o negro indefeso também se destaca. (SIMAS; FABATO, 2015).

18 No ano de 2019, a Mangueira apostou no enredo "História para ninar gente grande". O samba-enredo foi composto por Tomaz Miranda, Ronie Oliveira, Márcio Bola, Mamá, Deivid Domênico e Danilo Firmino.

19 Leandro Vieira (25 de julho de 1983) é figurinista e carnavalesco do Grupo Especial do carnaval do Rio de Janeiro. Desde 2016 é o carnavalesco da Estação Primeira de Mangueira.
} 
nativos do Brasil, que sofreram um genocídio quando os europeus aqui chegaram, atravessaram a Sapucaí da Verde e Rosa, e nos apresentaram a vasta cultura que carregam e que tiveram uma contribuição fundamental para a construção da identidade nacional. A agremiação também chama a atenção para o termo descobrimento e o desconstrói.

A história oficial data o "descobrimento" em 22 de abril de 1500. Mas como "descobrir" um território que já era ocupado há milhares de anos? A Mangueira conta então "a história que a história não conta. (...) $\mathrm{Na}$ primeira parte do desfile nos foi mostrado, a cerâmica secular dos índios tapajós ${ }^{20}$ e da civilização marajoara ${ }^{21}$. "O abre-alas reforça a presença de ocupação humana anterior ao descobrimento oficial, com indícios da existência dessas civilizações muito antes da chegada de Cabral, como evidenciaram, por exemplo, as pinturas rupestres da Serra da Capivara, com cerca de 50 mil anos. (VIEIRA, 2019, p 316).

A Mangueira decide então apresentar a outra face da história indígena que foi silenciada, mas que corre nas veias de todos os brasileiros. A história para além de petecas, redes de balanço e mandioca. A versão da escola é um pouco mais profunda e honesta, no sentido de nos contar a verdade, e não o que contém nos breves capítulos incompletos dos livros de História. A segunda parte do desfile foi nomeada "Heróis de lutas inglórias" e busca resgatar personagens fundamentais para a história brasileira, mas que não são reconhecidos. O título do setor faz alusão aos heróis e heroínas que lutaram, porém, não foram os vencedores, e a história dá voz e emoldura na parede quem "vence". Ao contrário do que se aprende nas escolas, os índios não foram pacíficos em relação a sua exploração. Havia formas de resistência como as guerras, as fugas, a manutenção de sua cultura e até o suicídio. "Alguns se organizaram de forma surpreendente, lideranças surgiram e, apesar da quase total dizimação, suas derrotas não anularam a importância de suas lutas". (IBID).

Esse setor destaca inúmeras revoltas indígenas ocorridas nos séculos XVI, XVII, XVIII, o que evidencia a permanência da resistência dos povos originários do Brasil por pelos menos três séculos ininterruptos. A mangueira também reforça a ideia de que o país foi "invadido" e não "descoberto" em um processo de genocídio sistemático que resultou na extinção completa de várias etnias. No entanto, é importante ratificar a resistência e luta dos povos indígenas que continuam se afirmando como parte da cultura e da identidade do Brasil até os dias de hoje, apesar da tentativa também incansável de silenciá-los.

\footnotetext{
20 Os Tapajós são um grupo indígena brasileiro, com remanescentes na área urbana de Santarém e na vila de Alterdo-chão. No século XVII, controlavam uma extensa área entre os municípios de Juruti e Prainha, no estado do Pará. ${ }^{21}$ Os Marajoaras foram uma sociedade que nasceu na ilha de Marajó ou Rio Amazonas na Era pré-colombiana. Considera-se que a cultura marajoara se subdivide em várias fases distintas, refletindo níveis de ocupação e desenvolvimento da sociedade, sendo as de Ananatuba, Mangueiras, Formiga, Acauã, Alta Marajoara e Aruã.
} 
"Nem do céu, nem das mãos de Isabel" é o título do terceiro setor do desfile que vai abordar o protagonismo negro. O grupo identitário, que também carrega em sua história resistência e luta, foi igualmente silenciado e, por isso, não recebe o destaque que merece nas páginas dos livros escolares. A Mangueira, portanto, questiona e reflete sobre o fato de a Princesa Isabel ter ganhado a notoriedade da abolição e resumir o fim da escravidão no Brasil a uma ação do Estado Brasileiro que resultou na assinatura da Lei Áurea em 1888.

De um modo geral, não são difundidos os nomes daqueles cujos feitos pressionaram para a eliminação do trabalho escravo; para as rebeliões que amedrontaram o sistema escravagista; para a formação de quilombos; para a compra de alforrias por irmandades negras; para a organização intelectual do movimento abolicionista, entre outras situações. (VIEIRA, 2019, p.317).

Seguindo essa linha de raciocínio, a escola traz nomes de lideranças negras que tiveram destaque na luta contra o cativeiro mas são desconhecidos dos brasileiros. Nomes como os de Tereza de Benguela ${ }^{22}$, Acotirene ${ }^{23}$ e Luís Gama ${ }^{24}$, entre outros, ganharam luz na Avenida da Estação Primeira de Mangueira. A escola ressalta também a importância da participação feminina nessa luta, quase nunca presente nos livros. A Verde e Rosa sublinha o nome de Dandara - no desfile veio representada pela cantora Alcione - mulher negra, capoeirista, líder da resistência e companheira de Zumbi - o maior símbolo da resistência negra veio personificado pelo cantor, compositor e presidente de honra da Mangueira, Nelson Sargento. ${ }^{25}$ No entanto, ao longo da história, apenas o nome do líder do quilombo dos Palmares é lembrado em datas específicas.

A quarta parte do desfile é batizada de "A história que a história não conta" e trata das contranarrativas, que consiste em desmitificar personagens que ganharam contorno heroico ao longo da história, mas que não nasceram de maneira natural. Heróis são símbolos de identificação coletiva, há aqueles que nascem de maneira espontânea, por meio do

\footnotetext{
22 Tereza de Benguela (1700- ?) foi uma líder quilombola na região do rio Guaporé, que fica no atual estado do Mato Grosso, durante o século XVIII. Após a morte de seu companheiro, José Piolho, Tereza se tornou rainha do quilombo do Quariterêre no início dos anos de 1750. O dia 25 de julho é instituído no Brasil como o Dia Nacional de Tereza de Benguela e da Mulher Negra.

${ }^{23}$ Acotirene (não foram encontrados registros acerca da data de nascimento da matriarca de Palmares) chegou à Serra da Barriga - primeiro povoado quilombola - antes de Ganga-Zumba assumir o poder. Ela era a matriarca do Quilombo dos Palmares, exercia a função de mãe e conselheira dos primeiros negros refugiados na Serra da Barriga.

${ }^{24}$ Luís Gonzaga Pinto da Gama (1830-1882) foi um abolicionista, orador, jornalista, escritor e o Patrono da Abolição da Escravidão do Brasil. Nascido de mãe negra livre e pai branco, contudo, foi feito escravo aos 10 anos e permaneceu analfabeto até os 17 anos de idade. Conquistou judicialmente a própria liberdade e passou a atuar na advocacia em prol dos cativos, sendo já aos 29 anos autor consagrado e considerado "o maior abolicionista do Brasil".

${ }^{25}$ Nelson Sargento (1924-2021), além de cantor e compositor, foi também artista plástico, ator e escritor. O sambista era um dos mais importantes nomes entre os bambas da Mangueira, presidiu a ala de compositores e, posteriormente, a presidência de honra. Sua composição "Agoniza mas não morre", gravada por Beth Carvalho, é um dos sambas mais lendários da história e é dito como hino do samba, por exaltar a resistência da cultura popular até os dias de hoje. Nelson Sargento morreu no dia 27 de maio de 2021, aos 96 anos, vítima da covid-19.
} 
reconhecimento popular, e outros precisam de uma certa ajuda para se tornarem heróis. Este segundo exemplo se encaixa nos personagens que compõem a história brasileira, como o "descobridor" Pedro Álvares Cabral, o imperador Pedro I e o alferes Joaquim José da Silva Xavier, o famoso Tiradentes, este último é o símbolo máximo de como heróis podem ser construídos de maneira pensada. (VIEIRA, 2019, p. 318).

A agremiação apresenta uma outra versão da história "oficial" por meio de uma linguagem anedótica, chargista e em tom de caricatura, questionando seus mitos e heróis emoldurados na parede. A escola consegue levar o público à reflexão e a estimular um pensamento crítico de maneira leve, sarcástica e inteligente. A Mangueira desconstrói o caráter heroico dessas figuras que por séculos fizeram parte do imaginário coletivo da sociedade brasileira e ressalta que a história está em constante transformação. Há de se acompanhar.

O quinto e último setor, denominado "Dos brasis que se faz um país", encerra o desfile da Mangueira em tom de celebração e esperança. A escola busca exaltar a identidade popular como valor patriótico. Suas alas dão destaque para artistas que vieram de camadas mais pobres da sociedade como o artista plástico negro Aleijadinho. Exaltação também para o povo nordestino, que sofre discriminação até hoje, e às comunidades e os moradores das favelas e morros do Brasil afora. Heróis anônimos e silenciados pulam o carnaval da Mangueira. "O país que é negado à representatividade. Os descendentes dos heróis que deveriam estar no retrato". (IDEM, p.319)

A Mangueira termina o desfile com as cores verde e rosa para exaltar as multidões de "favelados". Figuras como a escritora brilhante, Carolina Maria de Jesus, moradora da favela do Canindé, Zona Norte de São Paulo, que sustentou seus três filhos catando papel nas ruas, é personificada nesses milhões de anônimos que compõem as favelas e periferias do país. 0 também "favelado" e gênio, Jamelão, que foi engraxate e vendedor de jornal, e se tornou a voz símbolo da Estação Primeira de Mangueira também veio representando seu povo.

E, por fim, a figura da vereadora Marielle Franco ${ }^{26}$ traz a representatividade de mulheres negras que vêm de comunidades, conseguem superar as adversidades, ingressam nas universidades e fazem suas vozes serem ouvidas para lutar pelos seus. A vereadora eleita teve a vida ceifada em 2018. A escola deixa seu recado: "É o Brasil assumindo a identidade do morro. "É a mangueira refletindo o Brasil". (VIEIRA, 2019, p.319).

\footnotetext{
${ }^{26}$ Marielle Franco (1979-2018) foi uma socióloga, formada pela PUC-Rio, e política. Filiada ao PSOL, elegeu-se vereadora para a legislatura 2017-2020. Foi assassinada a tiros no dia 14 de março com seu motorista Anderson Gomes, no bairro do Estácio. Até o fechamento deste trabalho, o caso ainda não havia sido solucionado.
} 


\section{1 - Brasil chegou a vez de ouvir as Marias, Mahins, Marielles, Malês}

Por muitas décadas, a voz hegemônica que se impunha no Brasil e no mundo era branca, masculina e heterossexual. Com o avanço do debate e aprofundamento acerca das pautas identitárias, outros grupos sociais também estão ocupando espaços que antes Ihes eram negados. Mulheres, negros, LGBTQIA+ e indígenas erguem suas vozes e punhos e falam por si, sem a "ajuda" de intermediários.

O mundo caminha, ainda que a passos lentos, na direção de uma sociedade plural e diversa, em que todas as esferas que a compõem devem ser ouvidas por direito. Em seu desfile, a Mangueira reforça a representatividade necessária para se alcançar esse "país que não está no retrato".

Na primeira parte do samba-enredo, a escola chama a atenção para o termo "descobrimento" do Brasil e o questiona. "Desde 1500 tem mais invasão do que descobrimento", diz o verso. Ao longo da história, os personagens que ganharam contorno heroico, muitas vezes, são construídos a partir da premissa na qual os vencedores são destacados, entram para os livros acadêmicos, viram nomes de rua, monumentos em praças, e, consequentemente, povoam o imaginário popular. Um exemplo histórico desse sistema, que exalta o opressor e silencia o oprimido, é a figura dos Bandeirantes. As bandeiras foram expedições que ocorreram durante o Brasil Colonial com diversos objetivos, entre eles, a exploração territorial, a busca de riquezas, e a captura de indígenas ou de africanos escravizados.

Os Bandeirantes, como eram denominados os homens à frente dessas expedições, foram responsáveis por estupros, massacres, escravização e incêndios em muitas aldeias indígenas brasileiras. Estes mesmos homens entraram para a história como heróis desbravadores e receberam um monumento no Parque do Ibirapuera, em São Paulo. Ao passo que os povos originários do país foram silenciados, ocupam algumas páginas dos livros de história e tampouco decoram museus, praças ou ruas.

Ainda na parte inicial do samba-enredo, a Verde e Rosa diz em seus versos que: "Tem sangue retinto pisado/ Atrás do herói emoldurado". Nesse sentido, para destrinchar historicamente o verso do samba, é importante destacar a figura de um personagem que tem sua biografia pouco conhecida, no entanto, seu nome batiza uma das maiores avenidas de São Paulo, a Rodovia Anhanguera." (VIEIRA, 2019, p327).

Trata-se do bandeirante Anhanguera, "Diabo velho" em tupi guarani - "Anhanga", diabo + "ûera", velho - apelido dado pelos índios a pai e filho, ambos de nome Bartolomeu Bueno da 
Silva. Eles lideraram expedições sangrentas que deixaram marcas profundas para os povos indígenas. Porém, para a história brasileira, o nome dos dois bandeirantes entrou para a gama de homens ilustres, símbolos de progresso e valentia, dignos de diversas homenagens, a mais expressiva é justamente a rodovia já citada acima. (IDEM, p.327)

Desse modo, a voz hegemônica de outrora, alimentada por esse sistema de opressão e exclusão, pôde se perpetuar durante muitos séculos e construir heróis com o objetivo de povoar o imaginário brasileiro, em sua maioria, sujos de sangue. Com a Estação Primeira, outras vozes e grupos ganharam destaque e, assim, isto evidenciou que a história brasileira e seus verdadeiros heróis e heroínas, que ficaram por muito tempo no ostracismo, a partir de agora serão reverenciados e não mais esquecidos.

Para representar a resistência negra, a agremiação trouxe em seus versos um personagem da história brasileira extremamente importante, no entanto, pouco conhecido. Cantado na avenida, o verso nos conta que "a liberdade é um dragão no mar de Aracati". O trecho faz referência ao jangadeiro Francisco José do Nascimento, também conhecido como Chico da Matilde, que desde a infância trabalhou a bordo de embarcações com o objetivo de contribuir para o sustento da sua mãe, a Matilde, razão de seu apelido. Chico da Matilde foi um dos líderes do movimento que culminou na abolição da província do Ceará e libertação de todos os escravos do estado cinco anos antes da abolição oficial em 1888 com a assinatura da Lei Áurea. Em 30 de agosto de 1881, já trabalhando na Capitania dos Portos do Ceará, fechou o porto de Fortaleza tendo, assim, impedido o embarque de escravos para outras províncias. Devido a esse feito corajoso e histórico, o jangadeiro negro e pobre ficou conhecido pela alcunha de "Dragão do Mar". (IDEM, p.332).

Para saudar o protagonismo feminino na luta contra o cativeiro, a Mangueira ressalta uma figura importante para a história brasileira. Luiza Mahin - que veio representada pela cantora Leci Brandão, que também carrega em sua biografia resistência e combatividade, sendo a primeira mulher a ingressar na ala de compositores da agremiação e ser uma militante das causas LGBT e negra - foi uma das mais importantes lideranças da Revolta dos Malês, rebelião de caráter racial que lutava pelo fim da escravização e a imposição do catolicismo como religião, ocorrida em Salvador em 1835.

Mulher negra, africana da nação Nagô, da tribo Mahin, veio para a Bahia como escrava, sempre recusou o batismo e a doutrina cristã, e após conseguir sua liberdade, para sobreviver, trabalhava como quituteira pelas ruas de Salvador. Luiza Mahin estava tão profundamente 
ligada à rebelião que, caso o movimento tivesse obtido êxito, Luiza teria sido coroada Rainha da Bahia. (VIEIRA, 2019, p 331)

"Salve os caboclos de julho/Quem foi de aço nos anos de chumbo". Os primeiros versos da segunda parte do samba-enredo resgatam a importância da participação indígena contra o colonialismo. A Mangueira nos conta que em 2 de julho de 1823 chegava ao fim a luta pela independência da Bahia sob o domínio português e que, portanto, essa batalha perdurou mesmo após o Grito do Ipiranga de D. Pedro I, em 1822. Os povos originários seguiram travando conflitos sangrentos com os portugueses mesmo depois do ato sereno do imperador. (VIEIRA, 2019, p 348).

Durante a resistência, a organização de diversas frentes formada por negros libertos e escravizados, indígenas e pessoas de camadas mais baixas da sociedade em prol da liberdade, quebra, portanto, a ideia romantizada e pacífica do que foi a Independência do Brasil. 0 Desfile do Dois de Julho é um cortejo que acontece todos os anos nesta data na cidade de Salvador. A celebração, cujo dia é feriado estadual baiano, comemora exatamente a vitória sobre as forças coloniais na luta pela independência.

Dito isto, a Verde e Rosa, nos apresenta, por meio desse enredo e samba-enredo, a história que nos foi negada e nos mostra a trajetória de figuras centrais para a história e cultura do país. Heróis e heroínas de lutas inglórias que ficaram por séculos atrás do herói emoldurado na parede. É sabido que o mundo está mudando, e uma escola de samba carioca escolher resgatar tais heróis evidencia a nossa sede por outros tipos de heróis e heroínas, aqueles dignos de homenagem e reverência. A mangueira saúda os heróis que sangraram e não os que fizeram sangrar.

\section{Considerações Finais}

O poema "Canção de regresso à pátria", do poeta modernista Oswald de Andrade, ${ }^{27}$ faz uma paródia contra a alienação social existente no país durante os anos 1920. Uma das principais características do Movimento Modernista no Brasil era o nacionalismo crítico. O poema em questão exalta o protagonismo negro personificado por Zumbi dos Palmares e ressalta a importância de preservarmos e valorizarmos nossas riquezas naturais. Afinal, o Brasil é o número 1 em biodiversidade do mundo.

\footnotetext{
27 José Oswald de Sousa de Andrade (1890-1954) foi um poeta, escritor, ensaísta e dramaturgo brasileiro, de São Paulo. Oswald de Andrade foi um dos promotores da Semana de Arte Moderna de 1922, tornando-se um dos grandes nomes do Modernismo brasileiro ao lado de figuras como Mario de Andrade, Anita Malfatti, Tarsila do Amaral e Pagu.
} 
Minha terra tem Palmares/Onde gorjeia o mar/Os passarinhos daqui / Não cantam como os de lá/Minha terra tem mais rosas/ E quase que mais amores/Minha terra tem mais ouro/Minha terra tem mais Terra (...) (ANDRADE, 1925)

Traçando um paralelo com os dias de hoje, em que há uma tentativa de apagar vozes de diversos grupos identitários, torna-se necessário resgatar personagens que fazem parte da história brasileira e que precisam ser estudados e lembrados. A exemplo do que vem ocorrendo na Fundação Palmares, que tem feito uma "limpa" de personalidades relevantes para a cultura afro-brasileira em nome de uma ideologia. Diante disso, a crítica contra uma sociedade alienada continua sendo necessária e urgente.

A Mangueira, no ano de 2019, ao levar para a Avenida um enredo que exalta os heróis e heroínas esquecidos ou silenciados, cumpre o papel educativo e social que o samba e o carnaval promovem. Por meio da arte, a maior manifestação cultural do país, ofertar conhecimento, história e representatividade para a população é de uma riqueza imensurável. "História para ninar gente grande" nos elucida que nossa terra tem Palmares, Dandara, Chico da Matilde, Esperança Garcia, diversas etnias indígenas, e coloca os heróis emoldurados no seu devido lugar: de algozes e não de heróis.

Desse modo, os enredos e sambas-enredos estão recheados de passagens da nossa história, marcando a memória coletiva e afetiva da população e nos unindo como nação. O carnaval e o samba, no quesito papel transformador, educador, histórico e festive, sempre terão nota 10. A Verde e Rosa com seu enredo "História para ninar gente grande" não foi apenas campeã do carnaval de 2019, a Mangueira entende a função das agremiações na sociedade carioca e brasileira e trata com muito respeito nossa ancestralidade. Abram alas, que os heróis e heroínas de barracões vão passar.

\section{Referências bibliográficas}

GOMES, Antonio Henrique de Castilho. A [re]configuração do discurso do samba. Curitiba: Editora CRV, 2014.

LIESA. Abre Alas 2019 - segunda-feira. Disponível em:

http://liesa.globo.com/material/materia2019/publicacoesliesa/ ABREALAS/Abre-Alas\%20-

\%20Segunda-feira\%20-\%20Carnaval\%202019.pdf Acessado em 30/06/2021. 
SIMAS, Luiz Antonio e FABATO, Fábio. Pra tudo começar na quinta-feira: o enredo dos enredos. Rio de Janeiro: Mórula, 2015

LOPES, Nei. Dicionário da história da história social do samba.

Rio de Janeiro: Civilização Brasileira, 2015.

SODRE, Muniz. Samba, o dono do corpo. Rio de Janeiro: Mauad X, 1998. 